\title{
PENGEMBANGAN PEMBELAJARAN INTERAKTIF PERKULIAHAN DASAR-DASAR RANGKAIAN LISTRIK DENGAN BERBASIS INTERNET
}

\author{
Syaad Patmanthara \\ Fakultas Teknik Universitas Negeri Malang \\ email: Syaad_um@yahoo.co.id
}

\begin{abstract}
Abstrak: Teknologi informasi (internet) dimanfaatkan perguruan tinggi hanya sebagai media informasi kelembagaan tidak dalam hal proses pembelajaran. Hal ini terjadi juga di Universitas Negeri Malang, terutama pada masalah perkuliahan dasar-dasar rangkaian listrik di jurusan Teknik Elektro, Fakultas Teknik. Atas dasar ini, perlu dikembangkan produk pembelajaran interaktif berbasis internet (PIBI) yang didasarkan pada penerapan teori belajar. Untuk menghasilkan produk pengembangan dan penelitian yang dilakukan uji coba oleh para ahli dan mahasiswa. Subjek dipilih dalam pengembangan ini mahasiswa jurusan Teknik Elektro semester pertama dan semester ketiga. Kesimpulan akhir dari pengembangan ini adalah PIBI memiliki kekhususan pada aspek-aspek penampilan menarik, tes persyaratan, prates, tujuan pembelajaran, bahan ajar, soal latihan dan postes, dan rangkuman.
\end{abstract}

Kata Kunci: rangkaian listrik, pembelajaran interaktif, internet

\section{INTERACTIVE LEARNING COURSE DEVELOPMENT OF BASIC ELECTRICAL CIRCUIT WITH INTERNET BASED}

\begin{abstract}
Technology information (internet) that utilized college is only used as a medium of institutional information not in terms of the learning process. This happens also at the State University of Malang, especially on the subject of electric circuits in the Department of Electrical Engineering, Faculty of Engineering. On the basis of these things, should immediately develop of internet assisted instructional learning products (PIBI) which is based on the application of learning theories. To gene rate product development, product study conducted by experts and trial stages. Subjects were selected in a trial which students of Department of Electrical Engineering first semester and third semester. The final conclusion of this development is PIBI have specificity on the aspects attractive appearance, test and pre-test prerequisites, learning objectives, materials, test training and post-test questions and summary.
\end{abstract}

Keywords: electrical circuit, learning interactive, internet

\section{PENDAHULUAN}

Pemanfaatan Teknologi Informasi (internet) di dalam pembelajaran telah membawa kita lebih menguatkan keyakinan akan pengetahuan untuk meningkatkan produktivitas karena pemanfaatan teknologi telematika tidak hanya menambah khasanah pengetahuan dan keterampilan, tetapi juga kita dapat mengetahui bahwa masih terdapat digital divide dan information divide di Indonesia. Kenyataan menunjukkan bahwa teritegrasinya Teknologi Informasi (TI) dalam pembelajaran di dunia pendidikan merupakan suatu keharusan dan diharapkan menjadi budaya pengetahuan baru.

Perkembangan TI tidak dapat dipisahkan dengan perkembangan pendidikan. Dengan pe- nerapan TI di dalam pendidikan dapat menggunakan sarana komunikasi dan tidak ada batas ruang dan waktu untuk menggali ilmu pengetahuan secara global (Dryden \& Voss, 1999). Perkembangan teknologi informasi (e-learning, digital library, e-mail) tidak hanya dimanfaatkan oleh masyarakat pendidikan, tetapi juga untuk mengatisipasi perubahan sistem pembelajaran di masa akan datang.

Teknologi pembelajaran sebenarnya sudah cukup mumpuni untuk merubah sistem pembelajaran yang ada, terutama pada masalah belajar-pembelajaran (AECT:1997). Romiszwoski (1981:16-17) mengemukakan bahwa teknologi pembelajaran sebagai teknologi pengelolaan sumber-sumber belajar berpeluang untuk 
memberikan sumbangan dalam memecahkan permasalahan pembelajaran.

Pengamatan langsung di Jurusan Teknik Elektro Fakultas Teknik Universitas Negeri Malang (UM) terungkap bahwa (1) walaupun sebenarnya sistem jaringan komputer dan fasilitas jaringan internet yang dimiliki jurusan tersebut tetapi belum dimanfaatkan seoptimal oleh sebagai sarana belajar; (2) tidak tersedia pembelajaran berbantuan komputer sebagai sumber belajar selain buku teks; dan (3) kelas memiliki mahasiswa dengan kemampuan belajar yang berbeda-beda. Karena itu, perlu dikembangkan pembelajaran multimedia yang disesuaikan dengan perbedaan individual (Mayer, 2009). Salah satu teknik pembelajaran yang dapat digunakan secara individual adalah pembelajaran interaktif berbasis internet (PIBI); (4) mata kuliah dasar-dasar rangkaian listrik salah satu matakuliah keilmuan dan keterampilan listrik dasar, dipelajari dan wajib dikuasai mahasiswa.

Berdasarkan uraian di atas, perlu dikembangkan pembelajaran interaktif berbasis internet (PIBI) pada perkuliahan dasar-dasar rangkaian listrik di Jurusan Teknik Elektro Fakultas Teknik UM yang isinya sesuai dengan silabus yang berlaku dan dikembangkan berdasarkan prinsip-prinsip pembelajaran dengan memasukkan komponen-komponen yang dapat memudahkan belajar.

Tujuan tulisan ini sebagai berikut. (1) Mengembangkan pembelajaran interaktif berbasis internet (PIBI) berdasarkan rancangan pembelajaran Dick \& Carrey (1990) pada pada matakuliah rangkaian listrik di Jurusan Teknik Elektro Fakultas Teknik UM. (2) Menghasilkan produk PIBI yang telah dikembangkan dan diujicobakan kelayakannya pada Jurusan Teknik Elektro Fakultas Teknik UM. (3) Menghasilkan model produk PIBI di dalamnya terdiri dari: tampilan menarik, tes prasyarat dan prates, tujuan pembelajaran, materi, soal latihan dan pascates telah diujicobakan kelayakannya pada Jurusan Teknik Elektro Fakultas Teknik UM,

Produk yang dihasilkan dalam pengembangan dan penelitian ini adalah sebuah aplikasi pembelajaran interaktif berbasis internet dan disebut PIBI, meliputi: (1) PIBI dikemas secara menarik, penuh warna (colorfull), dan dilengkapi sajian animasi yang atraktif dan interaktif; (2) tampilan dan komposisi sajian setiap halaman web didesain secara proporsional dan seimbang, memperhatikan estetika dan mendayagunakan tempat (space) secara efektif, efesien dan harmonis; (3) akses mahasiswa untuk mengikuti pembelajaran diatur oleh kode akses (sebagai user atau tidak); (4) tahapan kegiatan pembelajaran dirancang secara sistematis dan terpadu dengan mengikuti tes prasyarat, prates, materi yang didisain menarik, soal latihan, pascates dan rangkuman. Pembelajarannya dapat dilakukan berulang; (5) PIBI menyediakan alat kontrol tingkat kecepatan belajar; (6) PIBI menyediakan program layanan komunikasi dan konsultasi melalui pemanfaatan e-mail.

\section{METODE}

Tujuan dari pengembangan ini menghasilkan produk pembelajaran Interaktif berbasis internet (PIBI) media pembelajaran ini yang sekaligus dapat digunakan sebagai sumber belajar. Melihat dari tujuan tersebut maka peneliti dan pengembang media ini mengacu pada salah satu metode pengembangan media yaitu model pengembangan rancangan pengajaran Dick dan Carey (1990). Langkah-langkah model pengembangan rancangan pengajaran Dick and Carey ditunjukkan pada Gambar 1.

Model tersebut mempunyai langkahlangkah: (1) mengenali tujuan pengajaran; (2) melakukan analisa pengajaran; (3) mengenali tingkah laku masukan dan ciri siswa; (4) merumuskan tujuan performansi; (5) mengembangkan butir-butir tes acuan patokan; (6) mengembangkan strategi pengajaran; (7) mengembangkan dan memilih material pengajaran; (8) merancang dan melakukan penilaian formatif; (9) merevisi pengajaran; (10) merancang dan melakukan penilaian sumatif. Namun, dalam pengembangan media pembelajaran ini, tahapan merancang dan melakukan penilaian sumatif tidak digunakan (Munandir, 1987). Hal ini disebabkan pengembangan yang dilakukan tidak sampai dalam uji lapangan untuk mengukur hasil belajar siswa. 


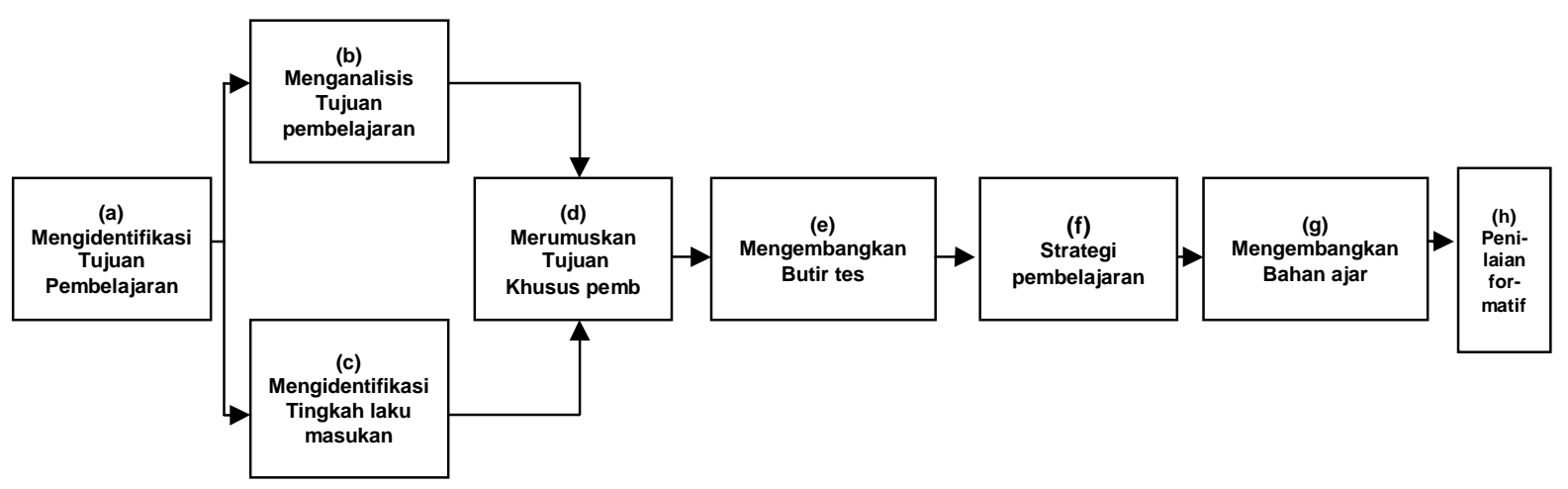

\section{Gambar 1. Model Pengembangan Pebelajaran Dick dan Carey (1990)}

Pemilihan model rancangan pembelajaran Dick dan Carey (1990) sebagai dasar pengembangan pembelajaran berbasis internet (PIBI), antara lain: (1) model ini mempunyai langkah-langkah yang sistematik dan rinci yang pada dasarnya merupakan salah satu ciri pokok teknologi pembelajaran; (2) langkah-langkah prosedur itu saling berhubungan; (3) urutan pengorganisasiannya sesuai dengan struktur matakuliah di Jurusan Teknik Elektro; dan (4) dapat membantu untuk memecahkan masalah belajar.

Pengembangan PIBI ini memanfaatkan kaidah teknologi pembelajaran dalam mengatasi salah satu faktor penghambat proses pembelajaran di Jurusan Teknik Elektro FT, dilakukan pengembangan salah satu jenis sumber belajar yang berupa bahan, yaitu PIBI. Pengembangan ini dalam kawasan teknologi pembelajaran merupakan usaha untuk memenuhi fungsi pengembangan sumber belajar. Melalui cara ini, hambatan belajar terutama yang berkaitan dengan keterbatasan sumber belajar diharapkan dapat teratasi.

Selain memenuhi fungsi pembelajaran dalam kawasan teknologi pembelajaran, pengembangan PIBI ini juga sejalan dengan perkembangan pengertian teknologi pembelajaran yang mutakhir: "instructional technologi is the theory and practice of design, development, utilization, management and evaluation of processes and resources for learning" (Seels dan Richey, 1994:9).

Untuk dapat menghasilkan PIBI yang berkualitas, perlu dilakukan perancangan dan pengembangan sesuai dengan prosedur sebagai berikut. (1) Pengembangan pembelajaran internet yang efektif, selalu diawali analisis kebutuhan belajar (need analysis), atau masalah-masalah yang muncul dalam pembelajaran (Bullen, 2001; Hartanto dan Purbo, 2002; Soekartawi dkk, 1999; Hasim dan Razmah, 2001). (2) Perencanaan awal yang perlu dilakukan adalah analisis karakteristik mahasiswa yang akan menggunakan, materi yang tidak dapat diabaikan dalam rumusan tujuan (Burke, 1982: Dick dan Carey, 1990). Dalam perencanaan awal perlu mempertimbangkan latar belakang pendidikan mahasiswa (learning analysis), materi yang relevan (learning unit analysis) (Soekartwai dkk, 1999; Hasim dan Razmah, 2001). (3) Pertimbangan mengenai strategi pembelajaran. (4) Perumusan tujuan yang harus dicapai pada pembahasan. (5) Perencanaan dan penyusunan butir tes dan strategi PIBI harus memiliki tiga keterampilan: menguasai bidang studi, menguasai prosedur pengembangan media, dan menguasai keterampilan teknis yang diperlukan dalam pemrograman komputer. Jika pengembang tidak menguasai beberapa di antara keterampilan tersebut, maka ia dapat mencari bantuan pihak lain, atau dengan meminjam istilah Kemp dan Dayton (1985) dapat melakukan team approach. (6) Isi bahasan dalam PIBI ini dijabarkan dari isi yang terkandung dalam pokok bahasan dan tujuan khusus pembelajaran diorganisasi sesuai dengan hirarki belajar (struktur belajar). (7) Produksi PIBI yang terdiri atas (a) materi dan teori; bagian ini merupakan inti dari seluruh isi materi pembelajaran; (b) simulasi dan visualisasi; memungkinkannya simulasi dan visualisasi materi teori dan memberi penga- 
laman pemahamanan yang berbeda dengan penjelasan di kelas; (c) latihan soal; mencakup didalamnya soal-soal yang dapat berkembang setiap saat sesuai dengan persiapan dari dosen; (d) quiz dan evaluasi evaluasi merupakan suatu keharusan yang diperlukan untuk menentukan kelulusan seseorang, hal ini dapat dilakukan secara online penuh; (e) tanya jawab interaktif dan diskusi; adanya diskusi dan interaksi secara langsung ataupun tidak langsung antara peserta dan pengajar. (8) Pembelajaran berbasis internet sudah siap untuk dikaji oleh ahli bidang studi, ahli rancangan pembelajaran, dan ahli komputer, serta mahasiswa untuk siap diujicobakan untuk mendapatkan masukan dan komentar. Masukan dan komentar yang diperoleh baik dari tinjauan para ahli maupun dari hasil ujicoba ini selanjutnya dijadikan pijakan untuk menyempurnakan produk.

Uji coba lapangan dilakukan pada 24 mahasiswa di semester I dan semester III untuk mengetahui penilaian mahasiswa terhadap model yang dikembangkan. Data yang digunakan dalam penelitian pengembangan ini adalah data deskriptif berupa yang diperoleh dari pengisian angket validasi ahli materi dan ahlimedia, hasil uji coba perorangan, kelompok kecil dan uji coba lapangan serta saran dan kritik yang diberikan oleh validator dan siswa. Instrumen yang digunakan dalam pengembangan media ini adalah instrumen berbentuk angket. Dalam pengembangan pembelajaran berbasis internet (PIBI) ini teknik analisis data sangat diperlukan. Teknis analisis data tersebut digunakan untuk menganalisis penilaian yang diperoleh dari uji coba produk. Berdasarkan teknik analisis data yang dikemukakan oleh Akbar (2010: 213), analisis data deskriptif adalah sebagai berikut.

$$
\mathrm{V}=\frac{\mathrm{TSEV}}{\mathrm{S}-\mathrm{max}} \times 100 \%
$$

Apabila dalam penilaian, PIBI dihasilkan valid, maka produk dapat dikatakan layak digunakan tanpa revisi jika nilai uji kelayakan di atas $85 \%$. Jika penilaian media yang dihasilkan tidak valid atau sangat tidak valid, maka PIBI tidak layak untuk digunakan dan perlu direvisi.
Revisi dilakukan berdasarkan saran dari validator dan subjek uji coba.

\section{HASIL DAN PEMBAHASAN}

Pada penelitian pengembangan ini menghasilkan suatu web pembelajaran interaktif berbasis internet (PIBI) sebagai media pembelajaran dinamis di Jurusan Teknik Elektro. Sebagai batasan pengembangan, maka dalam PIBI ini hanya dikembangkan pada perkuliahan dasar-dasar rangkaian Listrik di Jurusan Teknik Elektro. Namun, tidak menutup kemungkinan suatu saat dapat dikembangkan untuk matakuliah lain.

Pada halaman awal pembelajaran PIBI diberikan tampilan yang dimaksudkan untuk menarik perhatian mahasiswa. Bahan penarik perhatian dalam PIBI yang dikembangkan ini berupa gambar, diagram, tulisan bergerak (animasi), video dan nada. Sajian penarik perhatian ditujukan agar mahasiswa termotivasi untuk belajar secara mandiri sehingga tingkat ketuntasan belajar yang dicapai mahasiswa akan meningkat. (Marfuatun, Marwati dan Budiasih, 2012:263). Gambar terdiri dari dua buah: gambar pertama adalah animasi gambar-gambar seseorang yang sedang belajar melalui komputer dengan komunikasi jaringan internet, dan gambar kedua adalah gambar-gambar fasilitas jaringan internet yang sedang menyambut kehadiran mahasiswa yang baru saja usai belajar agar terdorong untuk belajar. Materi PIBI pada perkuliahan dasar-dasar rangkaian listrik ini diletakkan pada web jurusan. Tampilan awal PIBI ini divisualisasikan, seperti Gambar 2.

Prates dalam pembelajaran PIBI ini memiliki fungsi untuk mengukur penguasaan mahasiswa terhadap materi yang akan dipelajari, apabila mahasiswa telah mampu menguasai $100 \%$ dari prates, ia diasumsikan telah menguasai materi yang akan dipelajari. Oleh karena itu ia diberikan kebebasan untuk mempelajari pokok bahasan software PIBI ini selanjutnya. Jika mahasiswa menguasai kurang dari $100 \%$, maka ia harus mempelajari pokok bahasan materi pembelajaran tersebut pada software PIBI ini. Sebagai contoh prates seperti divisualisasikan, pada Gambar 3. 


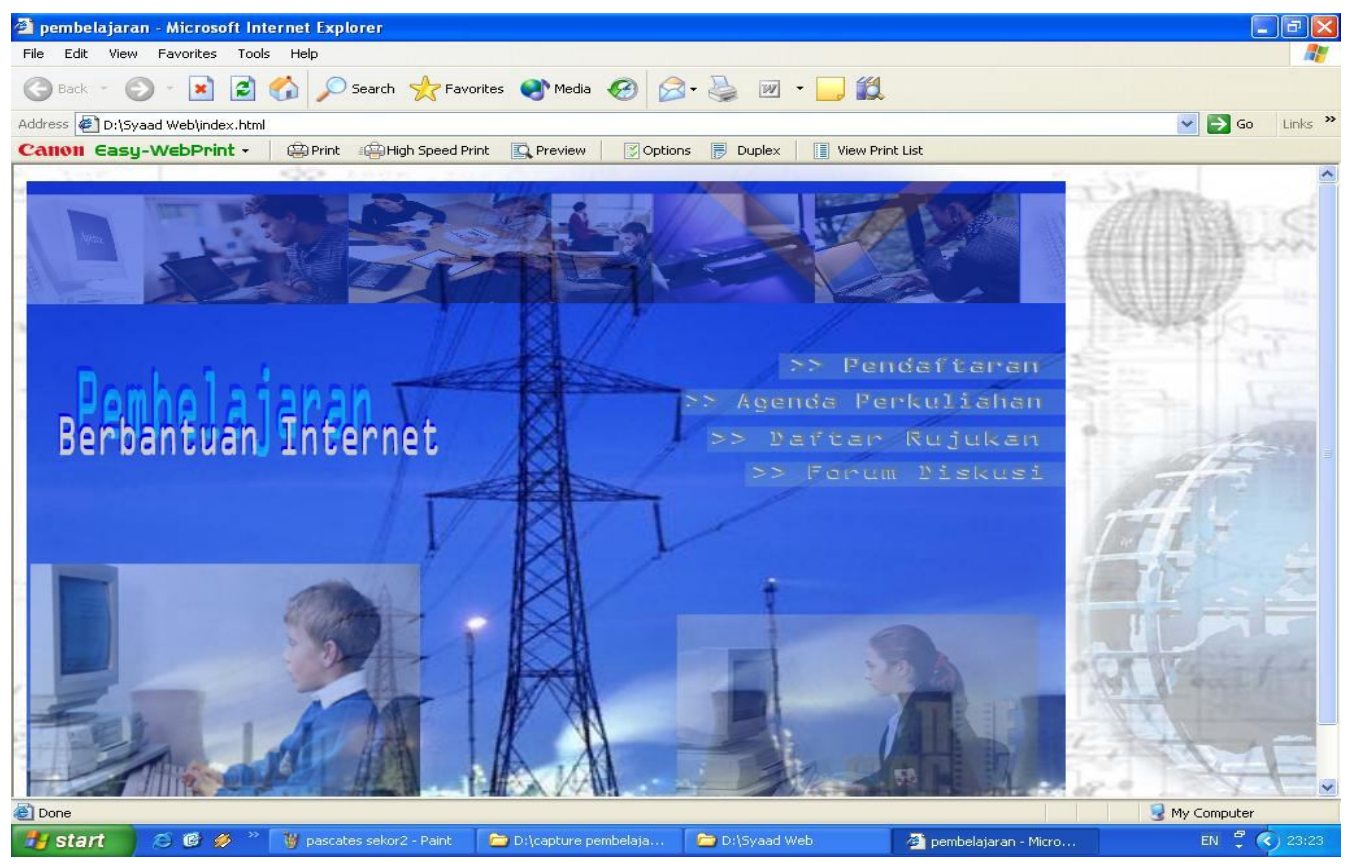

Gambar 2. Tampilan Awal

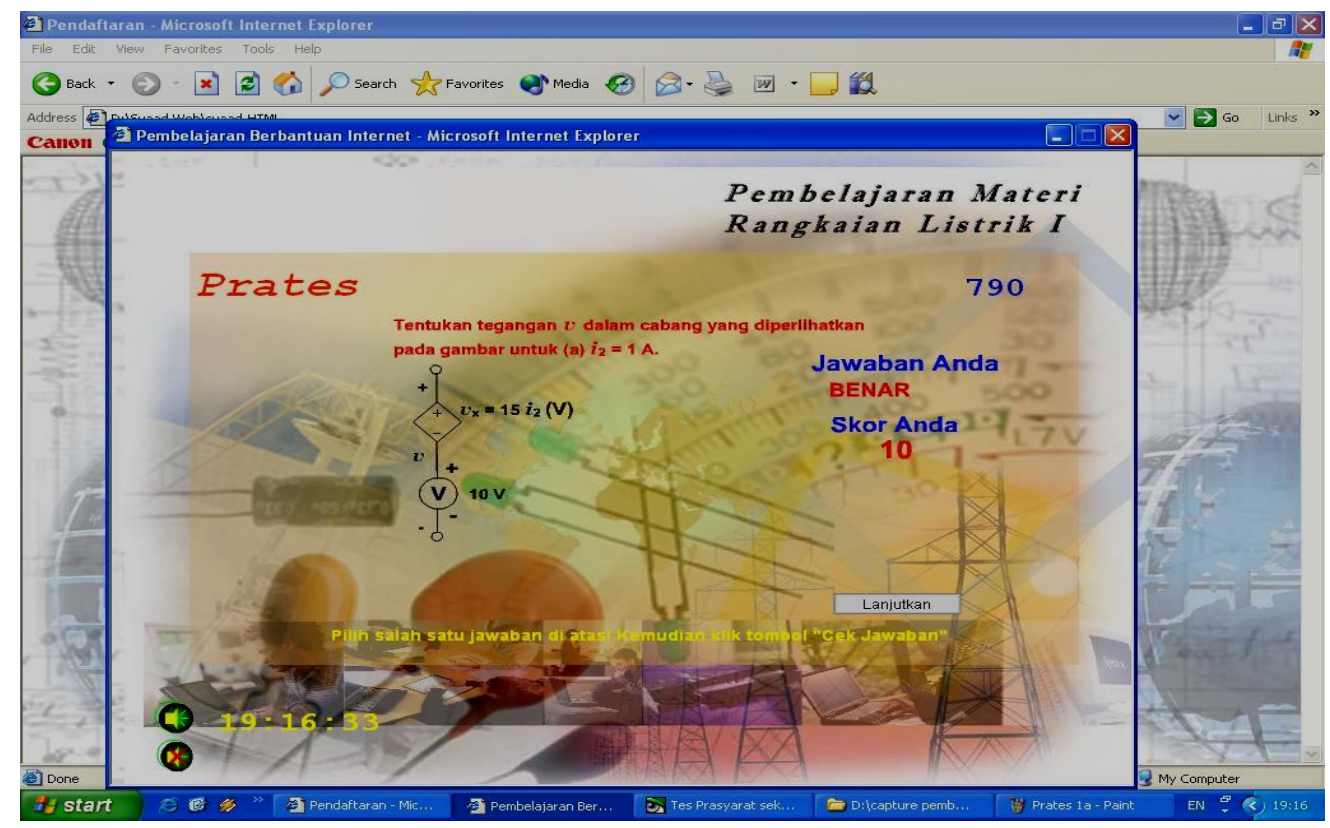

Gambar 3. Prates

Selanjutnya, analisis tujuan umum pembelajaran bertujuan untuk menentukan sub-sub keterampilan. Sub-sub keterampilan tersebut kemudian dirumuskan dalam tujuan khusus pembelajaran (TKP). Perumusan TKP ini berasal dari rumusan TKP yang dilakukan setelah langkah 1 (identifikasi tujuan pembelajaran), langkah 2 (analisis tujuan pembelajaran, dan langkah 3 (identifikasi tingkah laku masukan dan karaktersitik mahasiswa). Rumusan TKP mencakup empat komponen, yaitu (1) sasaran yang menggunakan PIBI; (2) deskripsi mengenai tuntutan kemampuan apa yang seharusnya dapat dilakukan mahasiswa setelah mempelajari 
PIBI; (3) kriteria keberhasilan yang dituntut atas unjuk kerjanya; dan (4) kondisi yang menjadi syarat pada saat mahasiswa menunjukkan kemampuannya. Sebagai contoh uraian tujuan khusus pembelajaran seperti divisualisasikan pada Gambar 4.

Isi bahasan dalam PIBI ini dijabarkan dari isi yang terkandung dalam pokok bahasan dan tujuan khusus pembelajaran. Isi bahasan ini termasuk ranah keterampilan intelektual sehingga urutan penyampaiannya diorganisasi sesuai dengan hirarki belajar (struktur belajar). Berdasarkan struktur belajar, keterampilanketerampilan tingkat lebih tinggi diletakkan di atas, sedangkan keterampilan-keterampilan tingkat rendah (yang menjadi prasyarat belajar) di bawahnya. Sebagai contoh uraian bahasan seperti divisualisasikan pada Gambar 5.

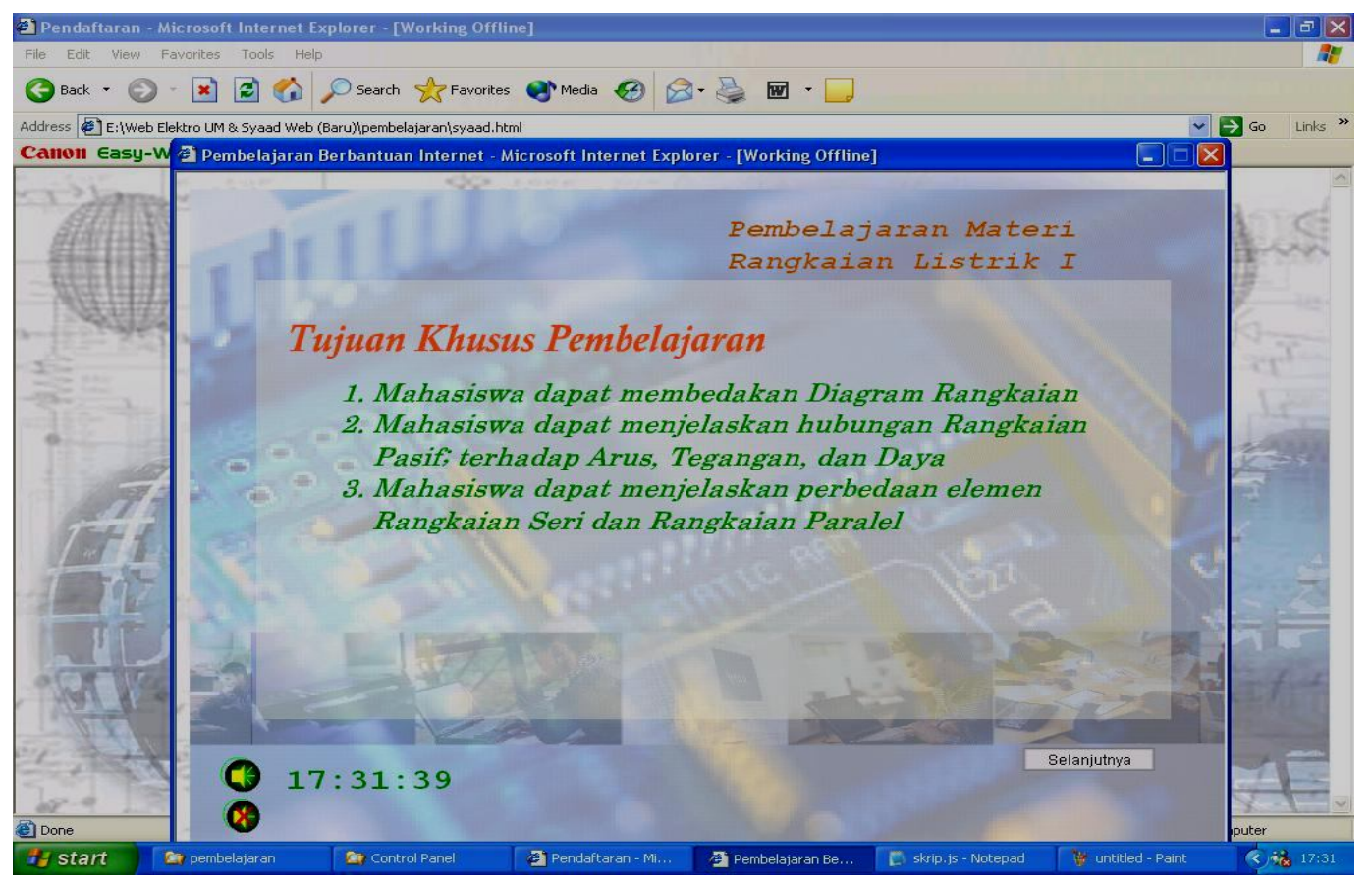

Gambar 4. Tujuan Khusus Pembelajaran

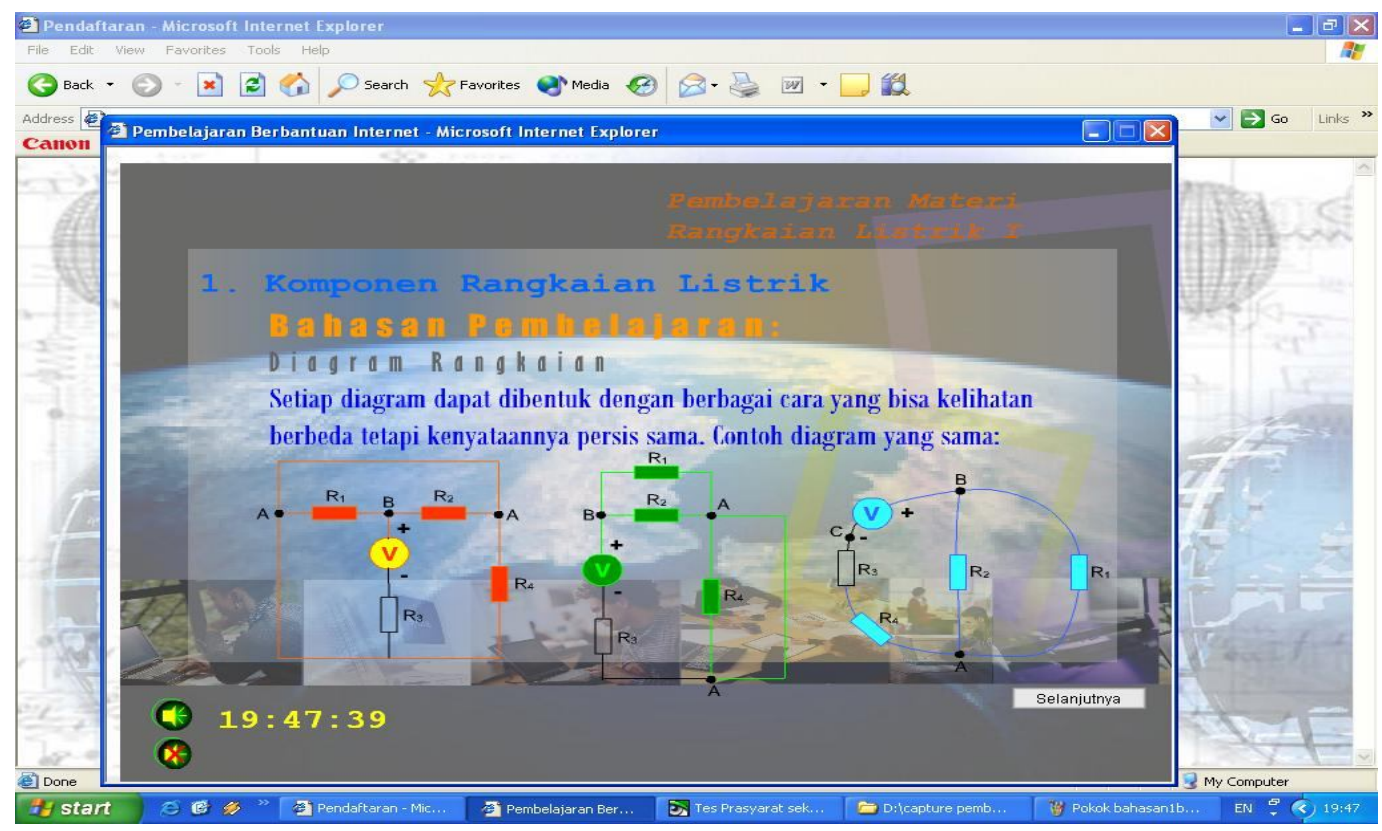

Gambar 5. Uraian Bahasan 
Soal-soal latihan dikembangkan dari rumusan butir-butir tes yang telah dirumuskan dari tujuan khusus pembelajaran. Jumlah soal disesuaikan dengan kebutuhan pada tujuan khusus pembelajaran dan dengan mempertimbangkan faktor waktu sebab terlalu banyak soal-soal latihan dapat berakibat pada durasi pembelajaran yang terlalu lama sehingga dapat menyebabkan kejenuhan dan kepenatan bagi mahasiswa untuk menyelesaikan software PIBI ini. Sebagai contoh soal-soal latihan seperti divisualisasikan pada Gambar 6.

Rangkuman disajikan untuk membantu mahasiswa meninjau kembali ide-ide pokok dari isi bahasan yang telah dipelajari serta membantu memudahkan mereka untuk mengingat kembali ide-ide penting yang disajikan dalam isi bahasan ini. Rangkuman disusun secara logis yang memuat ide-ide pokok dari isi bahasan dengan menggunakan bahasa yang mu- dah dicerna. Sebagai contoh rangkuman seperti divisualisasikan pada Gambar 7.

Pascates bertujuan untuk mengukur prestasi belajar mahasiswa, sejauhmana ia mampu mencapai tujuan khusus pembelajaran yang telah ditetapkan atau sejauh mana ia mampu menguasai isi bahasan yang telah dipelajari. Pascates digunakan sebagai alat pengukur prestasi belajarnya mengenai penguasaan pokok bahasan yang dipelajarinya dalam produk PIBI ini.

Pascates disusun dengan memperhatikan prinsip-prinsip penyusunan butir tes (1) disusun berdasarkan tujuan khusus pembelajaran dan isi bahasan yang disajikan sehingga dapat dijadikan alat yang mengukur apa yang seharusnya diukur; (2) sesuai dengan jenis-jenis soal yang telah diberikan dalam latihan (exercise); dan (3) identik dengan prates, yaitu memiliki cakupan isi yang sama, memiliki bentuk soal yang sama, dan memiliki tingkat kesulitan yang sama.

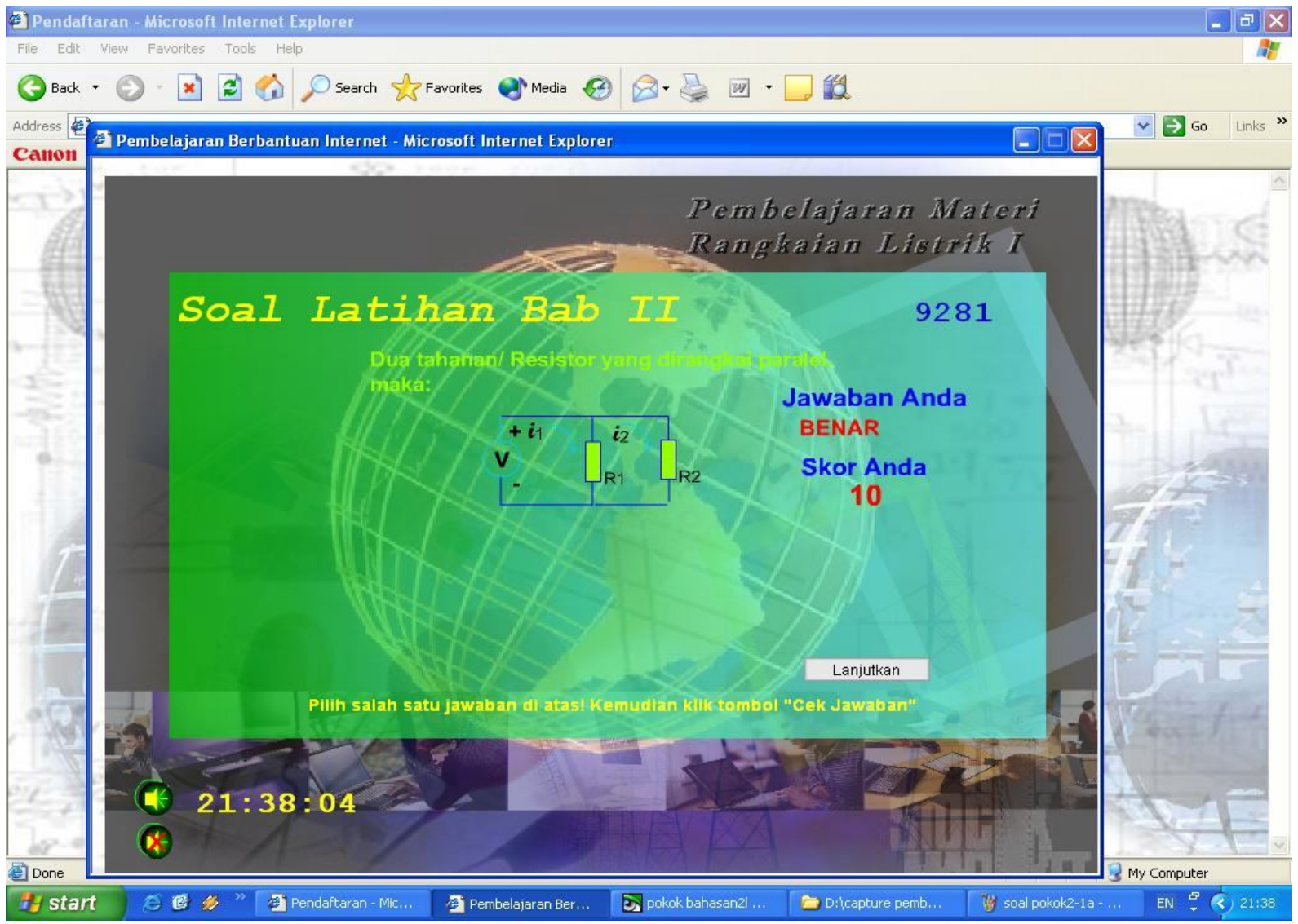

Gambar 6. Soal Latihan 


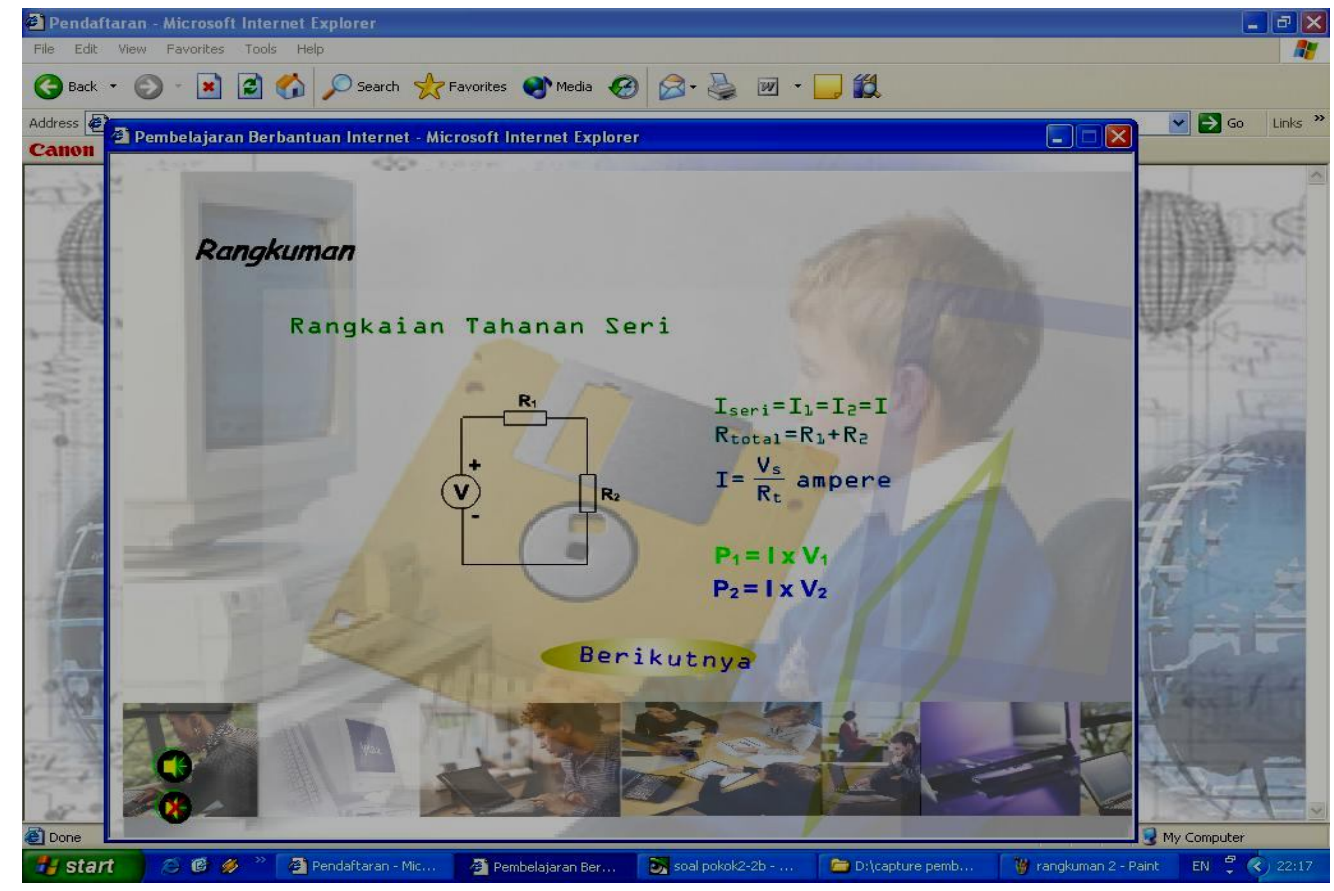

Gambar 7. Rangkuman

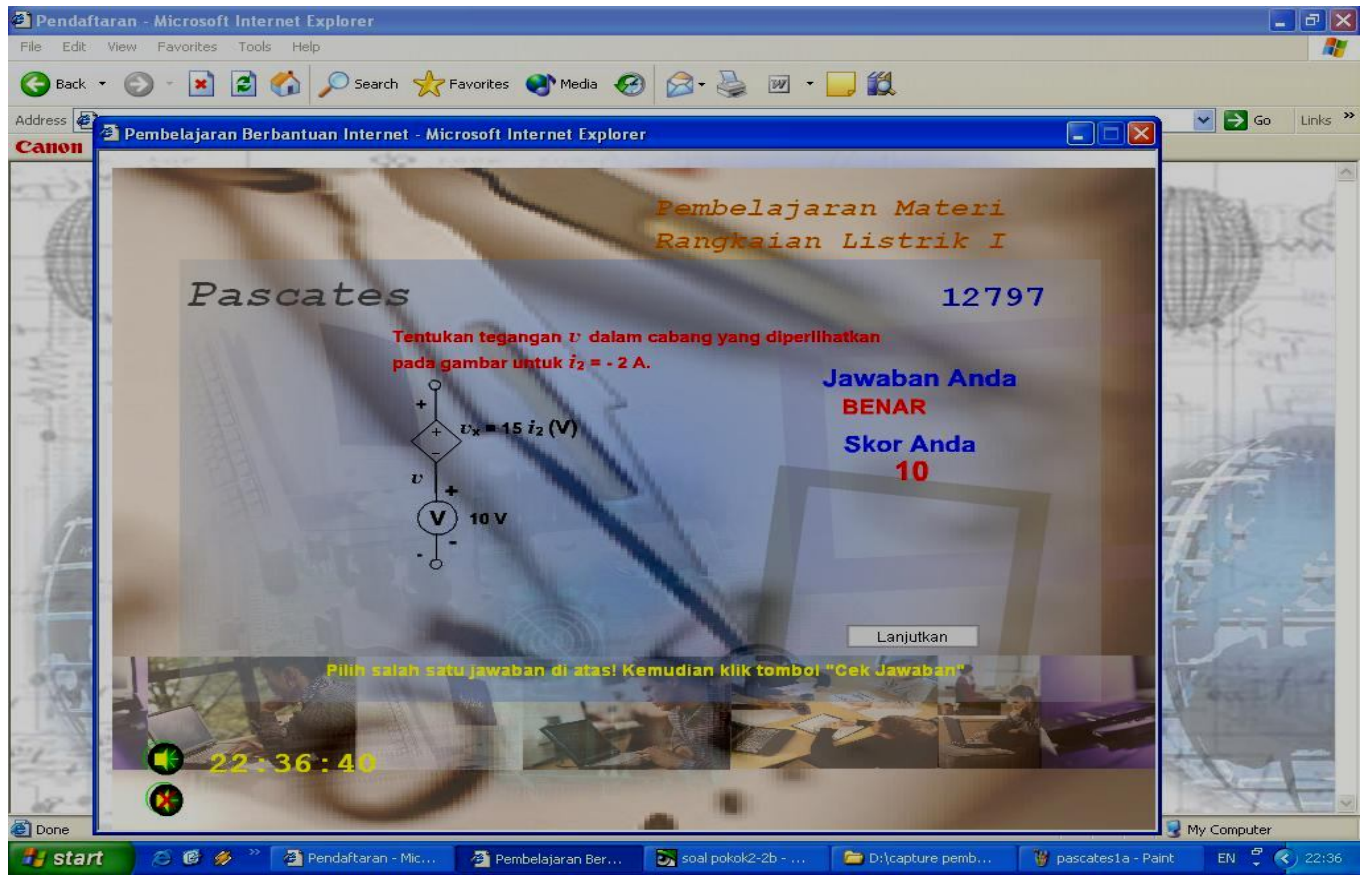

Gambar 8. Pascates

Sebagaimana halnya tes prasyarat dan prates, pascates pada PIBI ini juga dilengkapi waktu ini menggunakan program dimaksudkan untuk mengingatkan mahasiswa bahwa ia telah melampaui target waktu rata-rata pengerjaan pascates sehingga apabila target waktu telah terlampaui mahasiswa yang bersangkutan dapat mengerjakannya lebih cepat lagi dan tidak berlama-lama di sini. Oleh karena produk ini dikembangkan untuk pembelajaran individualisasi, maka pada prinsipnya mahasiswa dapat mengerjakan pascates ini cepat atau lambat sesuai dengan kemampuannya. 
Selain informasi mengenai target waktu pascates, dilengkapi pula dengan menu pilihan apakah mahasiswa ingin mengulang tes ini lagi untuk memperbaiki jawabannya atau tidak. Jika ia tidak ingin memperbaiki jawabannya ia dapat langsung mengakhiri tes tersebut. Pada akhir tes diberi informasi mengenai jumlah waktu yang telah dihabiskan mahasiswa untuk mengerjakan pascates ini, jumlah soal yang terjawab, jumlah jawaban benar, jumlah jawaban salah, serta informasi tentang nilai. Sebagai contoh pascates seperti divisualisasikan pada Gambar 8.

Penyajian dan analisis data diperoleh dari kegiatan uji coba produk, meliputi: (1) data hasil validasi ahli materi; (2) data hasil validasi ahli media; (3) data hasil uji coba kelompok kecil; dan (4) data hasil uji coba lapangan. Adapun hasil perolehan analisis data ditunjukkan pada Gambar 9.

Tampilan awal PIBI dengan sajian yang menarik bagi mahasiswa sehingga termotivasi dalam melaksanakan pembelajaran. Hal ini penting sekali agar mahasiswa termotivasi untuk belajar sehingga peristiwa-peristiwa pembelajaran berikutnya dapat berjalan dengan baikb (Gagne dan Briggs, 1988:157). Sajian yang menarik membuat kekuatan motivasi yang tinggi, dapat mengubah energi dalam diri mahasiswa menjadi bentuk aktivitas nyata untuk mencapai tujuan tertentu (Hamalik, 2001, Djamarah, 2006). Pada PIBI ini dilengkapi tujuan pembe- lajaran, dengan adanya tujuan pembelajaran mahasiswa lebih memahami materi yang harus dicapai. Hal ini didukung pendapat Aunurrohman (2009), bahwa penyajiaan tujuan belajar pada awal pembelajaran menguatkan retensi. PIBI disiapkan dengan materi yang terorganisasi sesuai dengan tujuan pembelajaran, sehingga materi pembelajaran akan bermakna. Bahan yang bermakna bagi mahasiswa dapat diserap lebih baik sehingga akan meningkatkan retensi (Aunurrohman 2009). Prinsip pengulangan digunakan pada PIBI ini sehingga akan mengembangkan daya pikir mahasiswa, mengingat, mengamati, dan menanggapi.

Hasil analisis menujukkan bahwa komponen bahan penarik perhatian yang telah melalui tahapan ujicoba, 92,8\% dapat diterima oleh uji coba dengan sejumlah persyaratan yang mendukungnya. Berdasarkan analisis ujicoba dan pernyataan para ahli tersebut di atas, dapat dinyatakan bahwa pada awal pembelajaran PIBI harus diberi bahan penarik perhatian yang berupa gambar, diagram, animasi, dan nada/suara.

Hasil analisis menujukkan bahwa tes prasyarat yang telah melalui tahapan ujicoba, $89,3 \%$ dapat diterima oleh uji coba. Tes prasyarat yang disajikan dalam PIBI memiliki keutamaan terutama dalam hal kepentingan untuk mengukur kemampuan awal mahasiswa sebelum dapat mengikuti atau mengakses materi pembelajaran pokok.

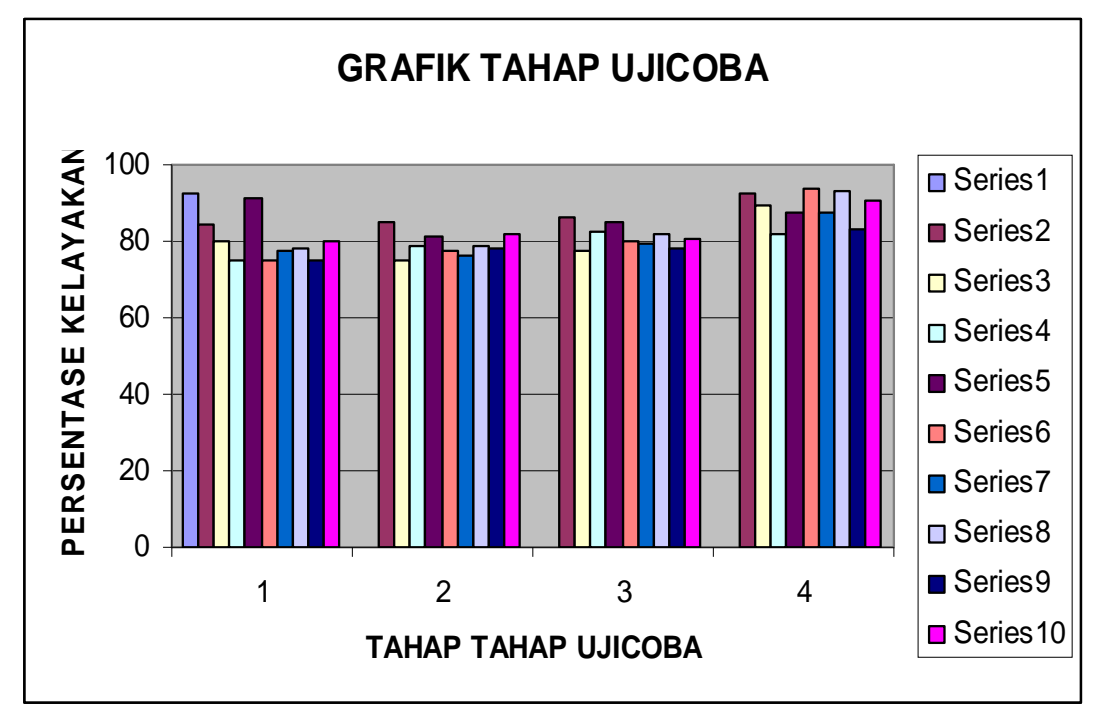

Gambar 9. Grafik Rekapitulasi Analisis Data 
Hasil tahap uji coba pada pengembangan komponen prates menujukkan bahwa $82 \%$ uji coba menerima produk PIBI. Prates digunakan untuk mengukur keterampilan yang akan diajarkan dalam pembelajaran. Hasil analisis penjelasan di atas bahwa ujicoba pembelajaran yang dilengkapi dengan prates dapat diterima oleh uji coba, dan didukung pula oleh para ahli maka pembelajaran tersebut dapat dinyatakan bahwa PIBI harus dilengkapi dengan prates.

Hasil analisis tahapan ujicoba pada tujuan pembelajaran menyatakan bahwa $87,3 \%$ subjek ujicoba dapat menerima tujuan pembelajaran yang digunakan pada produk PIBI. Dalam tujuan umum pembelajaran, mahasiswa diberi gambaran secara umum mengenai hal-hal yang akan dicapai mahasiswa setelah mempelajari PIBI ini. Dalam tujuan khusus pembelajaran mahasiswa diberi informasi mengenai hal-hal yang dicapai dan dikuasai setelah mengikuti setiap tahap pembelajaran ini.

Hasil analisis tahapan ujicoba pada materi pokok pembelajaran menunjukkan bahwa 93,5\% subjekuji coba menerima produk PIBI pada matakuliah rangkaian listrik di Jurusan Teknik Elektro Fakultas Teknik harus memperhatikan di antaranya (1) keterkaitan antara satu pokok bahasan dengan yang lain; (2) materi yang dikemas sebagai materi-materi pokok; (3) ilustrasi dan contoh ditampilkan untuk lebih memperjelas materi; dan (4) materi dikemas ke dalam bentuk gambar, bagan dan animasi untuk memudahkan pemahaman mahasiswa dan efisiensi dari segi penyajian.

Hasil analisis tahapan ujicoba menujukkan bahwa soal-soal latihan pada PIBI dapat diterima oleh $87,8 \%$ subjekuji coba. Hasil analisis penjelasan di atas bahwa ujicoba pembelajaran yang dilengkapi dengan soal-soal latihan dapat diterima. Hasil analisis tahap uji coba pada rangkuman menyatakan bahwa 93,2\% subjek ujicoba dapat menerima rangkuman yang digunakan pada produk PIBI. Berdasarkan analisis uji coba dan pernyataan para ahli tersebut di atas, dapat dinyatakan bahwa pada PIBI harus diberi rangkuman yang merupakan ide-ide penting yang berisi tinjauan kembali (review) terhadap apa yang telah dipelajari mahasiswa, sehingga tidak hanya memperkuat ingatan. Sejalan dengan penelitian yang dilakukan oleh Tambunan (2013) bahwa PIBI dapat memenuhi kebutuhan dasar dalam menunjangkegiatan pembelajaran, yaitu (1) memenuhi pengelolaan data materi pembelajaran; (2) memenuhi proses pembelajaran secara kontruktivis; (3) disajikan dengan materi pembelajaran yang interaktif; (4) dapat diunduh oleh mahasiswa, dan menampilkan materi dalam bentuk link; (5) memenuhi proses evaluasi sehingga dapat diketahui tingkat penguasaan mahasiswa tentang materi pembelajaran; dan (6) materi dibuat dalam bentuk animasi dengan menggunakan macromedia flash, video, dan teks.

Hasil analisis tahapan ujicoba pada pascates menyatakan bahwa $83,4 \%$ subjek ujicoba dapat menerima pascates yang digunakan pada produk PIBI. Pascates dapat digunakan sebagai alat pengukur prestasi belajarnya mengenai penguasaan pokok bahasan sesuai dengan tujuan pembelajaran yang telah dipelajarinya melalui PIBI ini (Zainul, 2001; Soekartawi, 2003; Harjanto, 1997). Dari analisis tahapan-tahapan ujicoba keseluruhan di atas dapat dikemukakan pada pembelajaran PIBI adalah sebagai berikut.

- Komponen bahan penarik perhatian PIBI adalah (1) penggunaan gambar yang berwarna-warni, (2) memunculkan animasi, (3) penggunaan nada atau lagu, dan (4) komposisi tampilan yang proposional (huruf atau gambar tidak terlalu kecil).

- Komponen tes prasyarat dan prates PIBI adalah (1) kalimat dan bahasa yang digunakan harus sederhana dan mudah untuk dipahami; dan (2) soal-soal yang ditampilkan bergerak dari soal yang mudah menuju yang sukar, namun penyajiannya ditata secara acak.

- Komponen Tujuan Pembelajaran PIBI disusun mengacu pada (1) rumusan tujuan perkuliahan; (2) ditetapkan berdasarkan hasil analisis kebutuhan dan tingkat kemampuan awal mahasiswa; dan (3) lebih banyak menyangkut aspek rumusan tujuan apada aspek kognitif. 
- Komponen materi pembelajaran yang dikembangkan adalah (1) menampilkan keterkaitan antara satu pokok bahasan dengan yang lain, (2) materi yang dikemas sebagai materi PIBI adalah materi-materi pokok, (3) ilustrasi dan contoh ditampilkan untuk lebih memperjelas materi, (4) materi dikemas ke dalam bentuk gambar, bagan dan animasi untuk memudahkan pemahaman mahasiswa dan efesiensi dari segi penyajian.

- Komponen soal-soal latihan (1) disusun sebagai bentuk evaluasi yang bertujuan pada perbaikan penguasaan materi pembelajaran bagi mahasiswa; (2) disusun sebagai prasyarat pencapaian hasil belajar pada satu satuan materi pembelajaran sebelum masuk pada materi bahasan berikutnya; (3) disusun berdasarkan tingkat kesulitan untuk mengerjakannya; (4) disusun dengan mengacu pada kepada materi pokok; (5) lebih banyak menampilkan soal-soal hitungan daripada soal uraian.

- Komponen pascates (sumatif) (1) disusun sebagai bentuk evaluasi hasil belajar mahasiswa setelah mengikuti dan melaksanakan pembelajaran secara keseluruhan; (2) disusun berdasarkan tingkat kesulitan untuk mengerjakannya; (3) disusun dengan mengacu pada materi pokok yang telah dipelajari; dan (4) lebih banyak menampilkan soal-soal hitungan daripada soal uraian.

- PIBI ini layak dipakai sebagai pembelajaran interaktif dan dapat digunakan dalam pembelajaran sebenarnya.

- PIBI sangat diperlukan atau dibutuhkan oleh mahasiswa maupun dosen karena dapat meningkatkan interaksi dan komunikasi antar mahasiswa, dan kolaborasi untuk berbagi sumber daya (Yun-Jo dan Williams, K, 2010).

- PIBI disarankan untuk selalu dikembangkan pada matakuliah ini karena software ini sangat membantu belajar mahasiswa pada perkuliahan dasar-dasar rangkaian listrik. Pembejaran berbantuan internet ini diberikan kepada peserta didik untuk belajar tidak hanya keterampilan komputer, tetapi juga sikap positif menggunakan Computer Asisted Learn- ing (Afshari, Ghavifekr, Siraj, dan Jung, 2013).

\section{PENUTUP}

PIBI dikembangkan dengan model rancangan pembelajaran Dick \& Carey, memiliki ciri khusus di ataranya: tampilan dan sajian bahan dikemas secari menarik, penuh warna (colorfull), dan dilengkapi sajian animasi gambar dan tayangan yang atraktif dan interaktif., halaman web didesain secara proporsional dan seimbang, dan adanya sistem seleksi pengguna. PIBI hasil pengembangan yang berisi: tampilan menarik, tes prasyarat dan prates, tujuan pembelajaran, materi, soal latihan dan pascates serta rangkuman materi yang dibahas.

PIBI pada matakuliah Rangkaian Listrik Idi Jurusan Teknik Elektro, layak dipakai sebagai salah satu model pembelajaran internet. Mahasiswa menyatakan bahwa PIBI yang telah dikembangkan tersebut memiliki nilai kepraktisan, kebermanfaatan, kesesuaian, kemenarikan dan memiliki tingkat kemudahan untuk dioperasikan dalam menunjang kegiatan belajar mahasiswa.

\section{UCAPAN TERIMA KASIH}

Ucapan terima kasih peneliti sampaikan kepada Redaktur Jurnal Cakrawala Pendidikan LPPMP Universitas Negeri Yogyakarta, teman sejawat mitra diskusi, subjek penelitian, Jurusan Teknik Elektro Universitas Negeri Malang.

\section{DAFTAR RUJUKAN}

AECT. 1997. Definition of Educational Technology. Associotion for Educational Communication and Technology. Washington, D.C

Afshari, Ghavifekr, Siraj, dan Jung. 2013. "Students' Attitudes Towards ComputerAssisted Language Learning". ProcediaSocial and Berhavioral Sciences, 103 (2013) hlm. 852-859

Akbar, Sadun. 2010. Pengembangan Kurikulum dan Pembelajaran Ilmu Pengetahuan Sosial (IPS). Yogyakarta: Cipta Media. 
Aunurrohman.2009. Belajar dan Pembelajaran. Bandung: Alfabeta

Bullen, M. 2001. "e-Learning and the Internationalization Education". Malaysian Journal of Educational Technology 1(1), 37-46.

Burke, 1982. Computer Assisted Instruction. Englewood Cliffs, New Jersey: Prentice Hall. Inc.

Dick, W dan Carey,L. 1990. The Systematic Design of Instruction. (third ed). Harper Collins Publisher

Djamarah, S. B Zain. 2006. Strategi Belajar Mengajar. Jakarta: Asdi Mahasatya.

Dryden \& Voss. 1999. The Learning Revolution: To Change the Way the World Learn. The Learning Web, (Online), (http://www.thelearningweb.net. Diakses 13 Januari 2004.

Gagne R. M. dan Briggs L. J. 1988. Principles of Intructional Design. New York: Holt Rinehart and Winston.

Hamalik, O. 2001. Proses Belajar Mengajar. Jakarta: Bumi Aksara.

Hartanto A. A dan Purbo O. W. 2002. Teknologi e-Learning Berbasis PHP dan MySQL. Jakarta: Media Komputindo.

Harjanto. 1997. Perencanaan Pengajaran. Jakarta: Rineka Cipta.

Hasim, Y. dan Razmah, B. M. 2001. An Overview of Inteructional Design and Development Models for Electronic Instruction and Leraning, Malaysian Journal of Educational Technology 1 (1), 1-7.

Kemp dan Dayton. 1985. Planing dan producing Intructioanl Media (Fifth Edition). New York: Happer \& Row, Publishers.
Marfuatun, Marwati dan Budiasih. 2012. "Pengembangan Media Pembelajaran Berbasis Program Director Mx pada Pembelajaran Topik Kimia Inti dan Radiokimia". Cakrawala Pendidikan, XXXI (2), hlm. 256-266.

Mayer E. R. 2009. Multimedia Learning: Prinsip-prinsip dan Aplikasi. Yogyakarta: Pustaka Pelajar.

Munandir. 1987. Rancangan Sistem Pengajaran. Jakarta: LPTK.

Patmanthara Syaad. 2004. "Pembelajaran Berbantuan Komputer Sebagai Manfaat Media Pembelajaran”. Jurnal Teknologi Elektro dan Kejuruan. Oktober 2004.

Romiszwoski, A. J. 1981, Designing Instructional Systems, London, Kogan Page.

Seels, B.B., dan Richey, R.C. 1994. Instructional Technology: the Definition and Domains of Field. Washington, DC: AECT.

Soekartawi, Suhardjono, T.Hartono dan A. Ansjarullah. 1999. Rancangan Instruksional. Jakarta: PT Rajawali Press.

Soekartawi. 2003. "Prinsip Dasar e-Learning: Teori dan Aplikasinya di Indonesia". Jurnal Teknodik. Oktober 2003.

Tambunan, H. 2013. "Pengembangan Pembelajaran Berbasis Website Dalam Matakuliah Pengaturan Mesin Listrik". Cakrawala Pendidikan, XXXII (1), hlm. 64-76.

Yun-Jo dan Williams, K. 2010. "Teachingwith Web 2.0 Technologies: Benefits, Barriers and Lessons Learned". International Journal of Instructional Technology and Distance Learning, 7 (3), hlm. 41-48.

Zainul, A dan Nasution, N. 2001. Penilaian Hasil Belajar. Jakarta: PAU: PPAI UT. 